\title{
A Life-Threatening Uterine Inversion and Massive Post Partum Hemorrhage Caused by Uterine Atony in A Primigravida Uterine Inversion
} Primigravid Hastada Hayatı Tehdit Eden Uterin Inversiyon ve Uterin Atoniye
Bağı Gelişen Postpartum Kanama

Işıl Uzun Çilingir, Volkan Atalay*, Ayşe Karahasanoğlu** , Barış Kaya*, Işık Akın** Acıbadem Bakırköy Hospital, Obstetrics and Gynecology, Istanbul, Turkey ${ }^{*}$ Gaziantep Maternity Hospital, Obstetrics and Gynecology, Gaziantep, Turkey

**süleymaniye Maternity Hospital, Obstetrics and Gynecology, istanbul, Turkey

\section{Abstract}

Uterine inversion is a rare and life-threatening complication of third stage of labour. It has been reported that the incidence of uterine inversion varies between 1 in 550 and 1 in several thousand in normal deliveries. The high maternal mortality rate may be attributed to associated life-threatening blood loss and shock. Herein, we report the case of a primiparous patient with uterine inversion in whom hysterectomy was performed in order to control bleeding. (The Medical Bulletin of Haseki 2013; 51: 139-40)

Key Words: Uterin inversiyon, histerektomi, postpartum kanama, atoni
Özet

Uterine inversiyon doğumun üçüncü evresinin sık rastlanmayan ve hayatı tehdit edebilen bir komplikasyonudur. Puerperal inversiyon sıklığı çalışmalarda 550 de bir ile bir kaç binde bir arasında değişmektedir. Maternal mortalite ilişkili kan kaybı ve ve şoka bağlı olarak \%15 lere kadar çıkabilmektedir. Biz burada primipar bir hastada histerektomiye neden olan ve şiddetli kanama ile seyreden bir uterin inversiyon olgusunu sunduk. (Haseki Tıp Bülteni 2013; 51: 139-40)

Anahtar Kelimeler: Uterine inversion, hysterectomy, postpartum bleeding, atony

\section{Introduction}

Uterine inversion is a life treating complication of vaginal delivery. If It is not recognized and treated immediately, life-threatening bleeding and shock may occur. The reported incidence varies between one in 2148 and one in 6407 births $(1,2)$.

We present the case of a primiparous patient with uterine inversion in whom hysterectomy was performed in order to control bleeding.

\section{Case}

20 years old nulliparous patient was admitted with regular contractions at the 41 weeks of gestation. She had no medical problems and all investigations were between normal limits. Oxytocin was used for augmentation. After 12 hours she gave a 3600 gr healthly boy. She had an uneventful vaginal delivery. The placenta remained adherent despite intermittent controlled cord traction. Nearly 20 minutes later, the placenta was at the cervical
Address for Correspondence/Yazışma Adresi: Işıl Uzun Çilingir

Acıbadem Bakırköy Hospital, Obstetrics and Gynecology, Istanbul, Turkey

E-mail: isiluzu@gmail.com

Received/Geliş Tarihi: 03 Şubat 2013 Accepted/Kabul Tarihi: 18 Mart 2013
The Medical Bulletin of Haseki Training and Research Hospital, published by Galenos Publishing. Haseki Tip Bülteni,

Galenos Yayınevi tarafından basılmışıı. 
os. At this time, approximately $500 \mathrm{ml}$ fresh blood loss has been occured. On the physical examination, the uterus was totally inverted. The placenta came spontaneously with further heavy blood loss of approximately $500 \mathrm{ml}$. There was no evidence of placenta accreta at the inspection of placanta.

A clinical diagnosis of acute inversion of uterus was made. Under anesthesia, vaginal manual reposition was attempted, which failed due to tight cervical ring. Total blood loss was estimated to be $1000 \mathrm{ml}$. Finally, abdominal reposition was planned and she was operated by Haultain's technique.After reposition of the uterus Intra venous oxytocin and metergine was adminestered to provide uterine contractions. Uterine contractions were not satisfactory to maintain hemostasis. Bilateral internal iliac artery ligation following bilateral uterine artery ligation were attempted to control bleeding, but, both were unsuccessful. At this time the patient's general condition was worsened. A heart rate of 150 beats/ minute, a thready pulse, prolonged capillary refill time, and an unrecordable arterial pressure was observed.. At the end of 5 units of packed red blood cells transfusion her haemoglobin was $5 \mathrm{~g} / \mathrm{dl}$. The decision was to perform hysterectomy because of ongoing severe blood loss.

Her post-transfusion haemoglobin at the end of the operation was $8 \mathrm{~g} / \mathrm{dl}$. She was totally transfused with 8 units of packed red blood cells. Her subsequent recovery was uneventful and she was discharged at the 8th day of the operation.

\section{Discussion}

Uterine inversion is the displacement of the fundus of the uterus. Uterine inversion usually occurrrs during the third stage of labour. It is a complete inversion when the fundus passes through the cervix, or incomplete if it remains above this level (3).

The causes of uterine inversion are not completely understood $(2,3)$.

The cases of uterine inversion has been investigated in several retrospective studies. It has been reported that the range of estimated blood loss was between $500-2500 \mathrm{ml}$ (4). Details of 11 uterine inversions were investigated in a retrospective study and a blood transfusion of between 2 and $5 \mathrm{U}$ of packed red cells were made only in three of these patients. Also cardiac arrest associated with uterine inversion has been reported as a case report (5).

Managament of uterine inversion should be step wise, comprising of non-surgical and surgical approaches. Surgical procedures are indicated when manual reduction fails. In our case the uterus was repositioned successfully by Haultain's technique, but uterine atony as a result necessiated hysterectomy

\section{References}

1. Platt $L D$, Druzin ML. Acute puerperal inversion of the uterus. Am J Obstet Gynecol 1981;141:187-90.

2. Shah Hosseini R, Evrard JR. Puerperal uterine inversion. Obstet Gynecol 1989;73:567-70.

3. Still DK. Postpartum hemorrhage and other problems of the third stage. In: James DK, Steer PJ, Weiner CP, Gonik B, eds. High Risk Pregnancy Management Options. London: WB Saunders Company Ltd, 1994;1175-7.

4. Brar HS, Greenspoon JS, Platt LD, Paul RH. Acute puerperal uterine inversion. New Approaches to Management. J Repro Med 1989;34:173-7.

5. Khalil A, Raafat A, Kalleja-Agius J, Bell R, O'Brien P. Cardiac arrest associated with uterine inversion during caesarean section. J Obstet Gynaecol 2006;26:696-7. 